\title{
Pengaruh Kepemimpinan Terhadap Motivasi dan Kinerja Karyawan pada Direktorat Jendral Administrasi dan Keuangan, Kementerian Estatal Timor Leste
}

\author{
Elvino Bonaparte do Rêgo ${ }^{1}$ \\ Wayan Gede Supartha ${ }^{2}$ \\ Ni Nyoman Kerti Yasa ${ }^{3}$ \\ 1,2,3 Fakultas Ekonomi dan Bisnis Universitas Udayana (Unud), Denpasar Bali \\ email: elvinobonaparte@yahoo.com
}

\begin{abstract}
ABSTRAK
Tujuan dari penelitian ini adalah untuk mengetahui pengaruh kepemimpinan terhadap motivasi kerja dan kinerja karyawan pada Direktorat Genderal Administrasi dan Keuangan Kementerian Estatal Timor Leste. Populasi dalam penelitian ini adalah seluruh karyawan Direktorat Genderal Administrasi dan Keuangan Kementerian Estatal Timor Jenis data yang digunakan adalah data primer dan data sekunder dengan metode pengumpulan data kuesioner. Alat analisis yang dipergunakan adalah analisis path. Hasil yang diperoleh dalam penelitian ini adalah kepemimpinan berpengaruh positif dan signifikan terhadap motivasi, artinya apabila kepemimpinan semakin baik, maka motivasi kerja meningkat. Motivasi mempunyai pengaruh positif dan signifikan terhadap kinerja karyawan, artinya apabila motivasi semakin baik, maka kinerja karyawan semakin meningkat. Kepemimpinan mempunyai pengaruh positif dan signifikan terhadap kinerja karyawan, artinya apabila kepemimpinan semakin baik, maka kinerja karyawan semakin meningkat. Oleh karena itu, ke depan untuk meningkatkan kinerja karyawan maka Direktorat Genderal Administrasi dan Keuangan Kementerian Estatal Timor Leste seharusnya mengembangkan kepemimpinannya agar semakin baik dan meningkatkan motivasi karyawan.
\end{abstract}

Kata Kunci : Kepemimpinan, Motivasi dan Kinerja Karyawan.

\begin{abstract}
The purpose of this study was to determine the effect of leadership on motivation and performance of employees in the Directorate of Administration and Finance Ministry Genderal Estatal East Timor. The population in this study were all employees of the Directorate of Administration and Finance Ministry Genderal Estatal Timorese. The data used are primary data and secondary data with the questionnaire data collection methods. The analysis tool is used path analysis. The results obtained in this study are positive and significant effect of leadership on the motivation, meaning that if the leadership is getting better, then the increased work motivation. Motivation has a positive and significant impact on the performance of employees, meaning that if the motivation is getting better, then the performance of employees is increasing. Leadership has a positive and significant impact on the performance of employees, meaning that if the leadership is getting better, then the performance of employees is increasing. Therefore, in the future to improve the performance of employees, the Directorate of Administration and Finance Ministry Genderal Estatal Timorese leadership should develop in order to get better and improve employee motivation.
\end{abstract}

Keywords: Leadership, Motivation and Employee Performance 


\section{LATAR BELAKANG}

Agar aktivitas manajemen berjalan dengan baik, Institusi harus memiliki karyawan yang berpengetahuan dan berketrampilan tinggi serta usaha untuk mengelola Institusi seoptimal mungkin sehingga kinerja karyawan meningkat. Menurut Budi Setiyawan dan Waridin (2006) kinerja karyawan merupakan hasil atau prestasi kerja karyawan yang dinilai dari segi kualitas maupun kuantitas berdasarkan standar kerja yang ditentukan oleh pihak Institusi. Kinerja yang baik adalah kinerja yang optimal, yaitu kinerja yang sesuai standar Institusi dan mendukung tercapainya tujuan Institusi. Institusi yang baik adalah Institusi yang berusaha meningkatkan kemampuan sumber daya manusianya, karena hal tersebut merupakan faktor kunci untuk meningkatkan kinerja karyawan

Peningkatan kinerja karyawan akan membawa kemajuan bagi Institusi untuk dapat bertahan dalam melakukan pelayanan terhadap masyarakat. Oleh karena itu upaya-upaya untuk meningkatkan kinerja karyawan merupakan tantangan pemimpin yang paling serius karena keberhasilan untuk mencapai tujuan tergantung pada kualitas kinerja sumber daya manusia yang ada didalamnya.

Kinerja karyawan tidak lepas dari peran pemimpinnya. Menutut Bass (1990), peran kepemimpinan dalam memberikan kontribusi pada karyawan untuk pencapaian kinerja yang optimal dilakukan melalui lima cara, yaitu: (1) pemimpin mengklasifikasikan apa yang diharapkan dari karyawannya, secara khusus tujuan dan sasaran dari kinerja mereka, (2) pemimpin menjelaskan bagaimana mmenuhi harapan tersebut, (3) pemimpin mengemukakan kriteria dalam melakukan evaluasi dari kinerja secara efektif, (4) pemimpin memberikan umpan balik ketika karyawan telah mencapai sasaran, dan (5) pemimpin mengalokasikan imbalan berdasarkan hasil yang telah mereka capai. Menurut Umar (2003), kinerja pegawai dapat dilihat dari dua sisi, 
yaitu internal (melalui penelaahan motivasi kerja dari pegawai itu sendiri) dan eksternal (ditelaah dari lingkungan kerja pegawai).

Negara Timor Leste merupakan Negara yang baru merdeka pada abat ke 21 ini, yang mana sangat membutuhkan pelayanan yang maksimal, karena pelayanan adalah kewajiban. Dalam hal ini pemimpin satuan kerja maupaun kepala bagian di Direktorat Administrasi dan keuangan Kementerian Estatal harus mampu melakukan pelayanan secara maksimal terhadap masyarakat dan berlaku adil kepada Kepala Sub Bagian maupun staf yang ada di masing-masing bagian.

Berdasarkan survei pendahuluan, yang dilakukan terhadap 30 karyawan menemukan adanya kekurangmotivasian yang diberikan institusi kepada karyawan, disamping gaya kepemimpinan yang cukup tinggi. Kemudian timbul pemikiran bagaimana keseluruhan faktor tersebut saling berkesinambungan sehingga mempengaruhi kinerja karyawan.

Motivasi sebagai proses yang bermula dari kekuatan dalam hal fisiologis dan psikologis atau kebutuhan yang mengakibatkan perilaku atau dorongan yang ditujukan pada sebuah tujuan atau insentif Moekijat 2001 dalam Hakim 2006. Beberapa peneliti telah menguji hubungan antara motivasi dengan kinerja karyawan, antara lain Suharto dan Cahyono (2005), Hakim (2006). Pengaruh motivasi kerja terhadap kinerja menunjukan hasil yang sama bahwa hubungan antara motivasi dengan kinerja karyawan menunjukan hubungan positif dan signifikan

Dalam hal ini yang menjadi permasalahan para Directur di lingkungan Direktorat Jendral Administrasi dan Keuangan adalah karyawan merasa bahwa Direktur belum mampu memenuhi kebutuhan fisiologi, kebutuhan keamanan dan keselamatan kerja, kebutuhan social, kebutuhan akan penhargaan dan kebutuhan aktualisasi diri, sehingga dapat menpengaruhi kinerja karyawan dalam melaksanakan 
tugas pokok dan fungsi yang telah diatur dalam Decreto Lei No. 7/2013 de 22 de Maio, Ornanica do Ministerio da Administrasaun Estatal (PP No.7/2013, 22 Mei, tentang Kedudukan Kementerian Estatal) Timor Leste, sehingga staf tersebut merasa bahwa motivasi yang dirasakan tidak sesuai dengan porsi mereka masing-masing. Maka dari itu sangat terpengaruh terhadap kinerja karyawan khususnya di Direktorat Jendral Administrasi dan Keuangan. Berikut ini adalah Tabel 1.1. mengenai data pegawai negeri di lingkungan Direktorat Jendral Administrasi dan Keuangan, Tahun 2012.

Tabel 1.

Data Karyawan di lingungan Direktorat Jendral Administrasi dan Keuangan,Tahun 2012.

\begin{tabular}{|c|c|c|c|}
\hline \multirow{2}{*}{$\begin{array}{c}\mathbf{N} \\
\mathbf{o}\end{array}$} & \multicolumn{2}{|c|}{ Nama unit kerja } & \multirow{2}{*}{$\begin{array}{c}\text { Jumlah } \\
\text { Karya } \\
\text { wan }\end{array}$} \\
\hline & Direktorat & Bagia & \\
\hline 1. & $\begin{array}{ll}\text { Sumber } & \text { Daya } \\
\text { Manusia } & \end{array}$ & 2 & 23 \\
\hline 2. & Humas dan Protokol & 2 & 17 \\
\hline 3. & Keuangan & 2 & 27 \\
\hline 4. & $\begin{array}{l}\text { Lofistik } \\
\text { Informasi }\end{array}$ & 3 & 65 \\
\hline 5 & $\begin{array}{lr}\text { Perencanaan } & \text { dan } \\
\text { hubungan } & \text { Luar } \\
\text { Negeri. } & \\
\end{array}$ & 2 & 20 \\
\hline & Tot a l & 11 & 152 \\
\hline
\end{tabular}

Sumber: Direktorat Administrasi dan Keuangan 2012.

Kepemimpinan merupakan gejala universal yang terdapat dalam kehidupan kolektif. Kepemimpinan mempunyai peranan sentral dalam kehidupan Institusi maupun berkelompok. Untuk mencapai tujuan bersama, manusia di dalam Institusi perlu membina kebersamaan dengan mengikuti pengendalian dari pemimpinnya. Dengan pengendalian tersebut, perbedaan keinginan, kehendak, kemauan, perasaan, kebutuhan dan lain-lain dipertemukan untuk digerakkan kearah yang sama. Dengan demikian berarti di dalam setiap Institusi perbedaan individual dimanfaatkan untuk mencapai tujuan yang sama sebagai kegiatan kepemimpinan. 
Suatu Institusi dibentuk untuk mencapai tujuan bersama, namun tuntuk mencapai tujuan secara efektif diperlukan pemimpin yang baik dan benar. Ada pendapat yang menyatakan bahwa kepemimpinan merupakan praktik spesifikasi yang mengubah sekumpulan orang menjadi kelompok yang efektif, berorientasi pada tujuan, dan produktif (Wibowi, 2007).

Faktor kepemimpinan dalam suatu Institusi memegang peranan penting karena pemimpin itulah yang akan menggerakkan dan mengarahkan Institusi dalam mencapai tujuan dan sekaligus merupakan tugas yang tidak mudah, karena harus memahami setiap pribadi bawahan yang berbeda-beda. Bawahan dipengaruhi sedemikian rupa sehingga bias memberikan pengabdian dan partisipasi kepada Institusi secara efektif dan efisien. Dengan kata lain, bawahan sukses tidaknya usaha pencapaian tujuan Institusi ditentukan olah kualitas kepemimpinan. Mengingat bahwa apa yang digerakan oleh seorang pemimpin bukan benda mati, tetapi manusia yang mempunyai perasan dan akal, serta beraneka ragam jenis dan sifatnya, maka masalah kepemimpinan tidak dapat dipandang mudah. Kemauan seorang pemimpin merupakan suatu sarana untuk mencapai tujuan. Hal ini berarti bawahan dalam memenuhi kebutuhannya tergantung pada ketrampilan dan kemampuan pemimpin (Sutrisno, 2009).

Dalam Institusi publik, bawahan bekerja selalu tergantung pada pemimpin. Bila pimpinan tidak memiliki kemampuan memimpin, maka tugas-tugas yang sangat kompleks tidak dapat dikerjakan dengan baik. Apabila pemimpin mampu melaksanakan fungsi-fungsinya dengan baik, sangat mungkin Institusi tersebut dapat mencapai sasarannya. Suatu Institusi membutuhkan pemimpin yang efektif, yang mempunyai kemampuan mempengaruhi perilaku anggotanya atau anak buahnya (Alimuddin, 2002). Jadi seorang pemimpin atau kepala suatu Institusi akan diakui 
Elvino Bonaparte do Rêgo, Wayan Gede Supartha, Ni Nyoman Kerti Yasa. Pengaruh...

sebagai seorang pemimpin apabila ia dapat memberi pengaruh dan mampu mengarahkan bawahannya ke arah tujuan Institusi.

Pada sebuah Institusi pemerintahan, kesuksesan atau kegagalan dalam pelaksanaan tugas dan penyelenggaraan pemerintahan, dipengaruhi oleh kepemimpinan, melalui kepemimpinan dan didukung oleh kapasitas Institusi pemerintahan yang memadai, maka penyelenggaraan tata pemerintahan yang baik (Good Governance) akan terwujud, sebaliknya kelemahan kepemimpinan merupakan salah satu sebab keruntuhan kinerja birokrasi (Istianto, 2009: 2).

Salah satu upaya yang dilakukan Direktorat Jendral Administrasi dan Keuangan adalah bagaimana mengelola sumberdaya yang tersedia untuk dimanfaatkan seoptimal mungkin demi mencapai tujuan. Oleh karena itu, setiap fungsi Direktur di Direktorat Jendral Administrasi dan Keuangan, bertanggung jawab dan mempunyai kewajiban untuk menyusun dan mengelola kebijaksanaan-kebijaksanaan dalam menggunakan dan mendapatkan sumberdaya-sumberdaya yang ada dalam Institusi tersebut. Untuk mendapatkan sumberdaya tersebut, perlu adanya perhatian besar dalam mengelola aspek-aspek psikologi, Institusional dan memadukannya dengan kemampuan individual baik keahlian, pengetahuan maupun pengalaman yang dimiliki agar kinerja karyawan dapat ditingkatkan. Dalam mengelola sumberdaya diperlukan pemimpin yang cakap, jujur, dan mempunyai kapabilitas manajer.

Motivasi sangat penting karena motivasi yang rendah dapat mempengaruhi kinerja karyawan yang rendah pula. Pada dasarnya motivasi dapat memacu kinerja karyawan untuk bekerja keras sehingga dapat mencapai tujuan mereka. Rivai (2005 menyatakan ada tiga motivasi sebagai berikut: (1) kemungkinan untuk berkembang, (2) jenis pekerjaan, (3) apakah mereka akan merasa banga menjadi bagian dari perusahaan tempat mereka kerja, sedangkan menutut (Hakim, 2006) motivasi adalah 
dorongan, upaya dan keinginan yang ada di dalam diri manusia yang mengaktifkan, memberi daya serta mengarahkan perilaku untuk melaksanakan tugas-tugas dengan baik dalam lingkup pekerjaannya. Robbins (2006) mendefinisikan motifasi sebagai proses yang ikut menentukan intensitas, arah, dan ketekunan individu dalam usaha mencapai sasaran. Motivasi sebagai proses yang bermula dari kekuatan dalam hal fisiologis dan psikologis atau kebutuhan yang mengakibatkan perilaku atau dorongan yang ditujukan pada sebuah tujuan atau insentif (Moekijat, 2001 dalam Hakim, 2006).

Disini, motivasi berperan sebagai pendorong kemauan dan keinginan untuk bekerja menurut ukuran-ukuran dan batasan-batasan yang diinginkan. Dengan adanya motivasi yang tinggi akan tercipta kinerja karyawan yang tinggi pula. Sehingga tujuan dan target yang ditetapkan Institusi akan tercapai.

Dalam penelitian ini mencoba mengetahui pengaruh kepemimpinan terhadap motivasi dan kinerja karyawan pada Direktorat Jendral Administrasi dan Keuangan. Dalam hal ini penting untuk diteliti karena di Direktorat Jendral Administrasi dan Keuangan yang terdiri dari 5 Direktorat dan 11 Bagian ini, peneliti merasa ingin mengetahui gaya kepemimpinan yang dilakukan apakah kepemimpinannya berpengaruh terhadap motivasi dan kinerja para pegawai di lingkungan tersebut.

Penelitian ini bertujuan membuktikan dan menganalisa pengaruh:

1) Pengaruh kepemimpinan terhadap motivasi kerja di Lingkungan Direktorat Jendral Administrasi dan Keuangan, Kementerian Estatal Timor Leste.

2) Pengaruh kepemimpinan terhadap kinerja karyawan di Lingkungan Direktorat Jendral Administrasi dan Keuangan, Kementerian Estatal Timor Leste.

3) Pengaruh motivasi terhadap kinerja karyawan di Lingkungan Direktorat Jendral Administrasi dan Keuangan, Kementerian Estatal Timor Leste. 


\section{KAJIAN PUSTAKA}

Kinerja karyawan merupakan bagian dari proses staffing. Proses ini di mulai dari proses rekrumen, seleksi, orientasi, penempatan, job, training awal dan proses penilaian kerja (Syafaruddin, 2001).

Kinerja adalah suatu kegiatan yang dilakukan manajemen atau penilai untuk menilai tenaga kerja dengan cara membandingkan kinerja atas kinerja dengan uraian atau deskripsi pekerjaan dalam suatu periode tertento. (Sastrohodiwiryo 2003).

Kinerja merupakan tahapan awal dalam upaya pengembangan sumber daya manusia. Perbaikan kinerja baik individu maupun kelompok menjadi pusat perhatian dalam upaya meningkatkan kinerja Institusi. Kinerja bertumpu pada kejelasan misi, strategi dan tujuan yang hendak di raih Institusi. (Yusuf Iranto 2001).

Manajemen atau penilai yang mempersiapkan diri untuk menilai kinerja seorang tenaga kerja sering menghadapi dua alternativef, yaitu; Pertama dapat menilai kinerja yang dihasilkan seorang tenaga kerja berdasarkan diskripsi pekerjaan yang telah ditetapkan. Kedua dapat menilai kinerja berdasarkan harapan-harapan pribadinya mengenai pekerjaan tersebut. (Sastrohadiwiryo 2003).

Hierarki manajemen merupakan salah satu proses penentuan keberhasilkan suatu lembaga atau perusahaan, karena setiap sumber daya manusia akan mengetahui hubungan diantara fungsi-fungsi atau bagian-bagian yang menunjukkan tugas, wewenang dan tanggung jawab yang berbeda. Secara umum ada 3 (tiga) tingkatan dalam klasifikasi manajemen diantaranya sebagai berikut:

a.Manajemen puncak.

b.Manajemen menengah, dan

c. Manajemen lini pertama. 
Dari ketiga hirarki manajemen tersebut masing-masing memiliki bawahan sesui dengan ruang lingkup yang di perlukan:

1.Manajemen menengah yang menjadi manajemen lininya adalah manajemen punak (top manajemen).

2.Managemen lini pertama (lower managemen atau First managemen) yang menjadi managemen lininya adalah managemen menengah (middle management)

3.Tenaga kerja operasional (tenaga kerja bisnis) yang menjadi manajemen lininya adalah manajemen lini pertama.

Kinerja adalah hasil kerja yang dicapai oleh seseorang atau sekelompok orang dalam suatu organisaisi, sesuai dengan wewenang dan tanggung jawab masingmasing. Dalam rangka mencapai tujuan Institusi bersangkutan secara legal, tidak melanggar hukum dan sesuai dengan moral dan etika. Rumusan di atas menjelaskan bahwa kinerja adalah tingkat keberhasilan sesorang atau lembaga dalam melaksanakan pekerjaan.

Dari defenisi di atas, terdapat setidaknya empat elemen yaitu :

1) Hasil kerja yang dicapai secra individual atau secara institusi, yang berarti bahwa kinerja tersebut adalah "hasil akhir" yang diperoleh secara sendiri-sendiri atau berkelompok.

2) Dalam melaksankan tugas, orang atau lembaga diberikan wewenang dan tanggung jawab, yang berarti orang atau lembaga diberikan hak dan kekuasaan untuk bertindak sehingga pekerjaannya dapat dilakukan dengan baik.

3) Pekerjaan harusnya dilakukan secara legal, yang berarti dalam melaksanakan tugas-tugas individu atau lembaga tentu saja harus mengikuti aturan yang telah ditetapkan. 
Elvino Bonaparte do Rêgo, Wayan Gede Supartha, Ni Nyoman Kerti Yasa. Pengaruh...

4) Pekerjaan tidaklah bertentangan dengan moral dan etika, artinya selain mengikuti aturan yang telah ditetapkan, tentu saja pekerjaan tersebut haruslah sesuai dengan moral dan etika yang berlaku umum.

Dalam mencapai tujuan Institusi yang telah ditetapkan, pimpinan melakukan tugas-tugasnya dibantu oleh pimpinan yang lain bersama dengan karyawan mereka. Keberhasilan pimpinan melaksanakan tugasnya akan dipengaruhi oleh kontribusi pihak lain artinya kinerja pimpinan akan dipengaruhi oleh kinerja individu, jika kinerja individu baik akan mempengaruhi kinerja pimpinan dan kinerja Institusi.

Penilaian kinerja adalah proses dimana Institusi mengevaluasi pelaksanaan individu. Penilaian kinerja individu sangat bermanfaat bgi dinamika pertumbuhan Institusi secara keseluruhan, melalui penilaian tersebut maka dapat diketahui kondisi sebenarnya.

Murphy dan Rivai (2005) mengemukakan bahwa ada tiga tujuan penilaian kinerja yang mempengaruhi penilaian yaitu :

1) Tujuan penilaian kinerja dapat langsung mempengarhi penilaian.

2) Tujuan penilaian kinerja tidak langsung mempengaruhi penilaian.

3) Tujuan penilaian kinerja dapat mempengaruhi dimana penilaian memasukkan informasi perilaku yang dinilai ketika membuat keputusan tentang kinerjanya.

Tujuan penilaian kinerja dapat memotivasi para karyawan jika evaluasi tersebut dapat menyakinkan para karyawan bahwa penilaian yang dilakukan adalah bagian dari apa yang mereka harapkan dihubungkan dengan peningkatan karyer mereka. Selain itu manfaat penilaian kinerja adalah suatu metode perbandingan sistemati dari pekerjaan-pekerjaan itu Soeprihanto (2001), dengan demikian ada tiga manfaat penilaian kinerja, yaitu :

1) Perbaikan kinerja. 
2) Penyesuaian kompensasi,,

3) Keputusan penempatan

Selain manfaat yang dikemukakan tersebut, ada juga masalah-masalah tertentu dengan digunakannya sesuatu rencana penilaian kinerja.

\section{Kepemimpinan}

Kepemimpinan merupakan suatu ungkapan yang mendudukkan posisi pemimpin dalam suatu Institusi pada posisi yang terpenting dan akan selalu mempertanggung jawabkan kepemimpinannya Thoha, (2007). Robbin (2006) menyatakan bahwa kepemimpinan adalah merupakan kemampuan untuk mempegaruhi kelompok menuju pencapaian sasaran. Kepemimpinan adalah suatu proses interaksi antara pemimpin dan karyawan dimana pemimpin berupaya untuk mempengaruhi karyawan untuk mencapai tujuan perusahaan atau Institusi Northousee, (2010); Yukl, (2005). Menurut Thoha (2007) kepemimpinan adalah sifat, karakter, atau cara seseorang dalam upaya membina dan menggerakkan seseorang atau sekelompok orang agar mereka bersedia, komitmen dan setia untuk melaksanakan kegiatan sesuai dengan tugas dan tanggung jawab untuk mewujudkan tujuan perusahaan yang telah ditetapkan sebelumnya. Dalam memotivasi karyawan, peran seorang pemimpin sangat dibutuhkan karena kepemimpinan merupakan suatu proses penggunaan pengaruh positif terhadap orang lain untuk melakukan usaha lebih banyak dalam sejumlah tugas atau mengubah perilakunya Yuki, (2001). Selain itu Gibson (2006) menyatakan bahwa kepemimpinan merupakan suatu usaha menggunakan pengaruh untuk memotivasi individu dalam nencapai beberapa tujuan. Menurut Josep C. Rost dalam Triantoro Safaria (2004) Kepemimpinan adalah sebuah hubungan yang saling mempengaruhi diantara pemimpin dan pengikut yang menginginkan perubahan nyata yang mencerminkan tujuan bersamanya. 
Kepemimpinan menurut Siagian (2002) adalah kemampuan seseorang untuk mempengaruhi orang lain dalam hal ini para bawahannya sedemikian rupa sehingga orang lain itu mau melakukan kehendak pemimpin meskipun secara pribadai hal itu mungkin tidak disenangi. Sedangkan Yulk (2001) mengatakan kepemimpinan adalah proses untuk mempengaruhi orang lain untuk memahami dan setuju dengan apa yang perlu dilakukan dan bagaimana tugas itu dilakukan secara efektif, serta proses untuk memfasilitasi upaya individu dan kelompok untuk mencapai tujuan bersama. Dalam memelihara komitmen Institusi, peran seorang pemimpin sangat dibutuhkan dan kepemimpinan yang efektif menjadi syarat utama. Kepemimpinan yang efektif dapat membantu Institusi untuk bertahan dalam situasi ketidakpastian dimas datang Katz dan Khan, (1978); Koh (1995); Mowday (1982) dalam Sovyia Desianty (2005). Selain itu Gibson (2006) mengatakan bahwa kepemimpinan sebagai suatu upaya penggunaan jenis pengaruh bukan paksaan untuk memotivasi orang-orang mencapai tujuan tertentu.

\section{Gaya Kepemimpinan.}

Menurut Veithzal Rivai (2004) gaya kepemimpinan adalah pola menyeluruh dari tindakan seorang pemimpin, baik yang tampak maupun yang tidak tampak oleh bawahannya. Gaya kepemimpinan menggambarkan kombinasi yang konsisten dari falsafah, ketrampilan, sifat, dan sikap yang mendasari prilaku seseorang. Gaya kepemimpinan menunjukkan secara langsung maupun tidak langsung, tentang keyakinan seorang pemimpin terhadap kemampuan bawahannya. Artinya, gaya kepemimpinan adalah perilaku dan strategi, sebagai hasil kombinasi dari falsafah, keterampilan, sifat, sikap, yang sering diterapkan seorang pemimpin ketika ia mencoba mempengaruhi kinerja bawahannya. 
Flippo (1994) gaya kepemimpinan dapat dirumuskan sebagai suatu pola perilaku yang dirancang untuk memadukan kegiatan-kegiatan institusi dan personalia guna mengejar beberapa sasaran. Didin Kurniadin \& Imam Machali (2012) gaya kepemimpinan adalah sekumpulan cirri yang digunakan pimpinan untuk mempengaruhi bawahan agar sasaran Institusi tercapai atau dapat pula dikatakan bahwa gaya kepemimpinan adalah pola perilaku dan strategi yang sering disukai dan sering diterapkan oleh seorang pemimpin.

Sedangkan Miftah Thoha (2012) menyatakan gaya kepemimpinan merupakan norma perilaku yang digunakan oleh seseorang pada saat orang tersebut mencoba mempengaruhi perilaku orang lain seperti yang ia lihat. Sehingga menyelaraskan persepsi diantara orang yang akan mempengaruhi perilaku dengan orang yang perilakunya akan dipengaruhi menjadi amat penting kedudukannya. Dalam teori jalur tujuan (Path Goal Theory) yang dikembangkan oleh Robert House (1971) dalam Kreitner dan Kinicki (2005) menyatakan bahwa kepemimpinan mendorong kinerja yang lebih tinggi dengan cara memberi kegiatan-kegiatan yang mempengaruhi bawahannya agar percaya bahwa hasil yang berharga bisa dicapai dengan usaha yang serius. Kepemimpinan yang berlaku secara universal menghasilkan tingkat kinerja dan kepuasaaan bawahan yang tinggi. Dalam situasi yang berbeda mengisyaratkan gaya kepemimpinan yaitu karakteristik personal dan kekuatan lingkungan. Teori ini juga menggambarkan bagaimana presepsi harapan dipengaruhi oleh hubungan kontijensi diantara empat gaya kepemimpinan dan berbagai sikap dan perilaku karyawan. Perilaku kepemimpinan memberikan motivasi sampai tingkat (1) mengurangi halangan jalan yang mengganggu pencapaian tujuan, (2) memberikan paduan dan dukungan yang dibutuhkan oleh para karyawan, dan (3) mengaitkan 
penghargaan yang berarti terhadap pencapaian tujuan. Selain itu, House mengatakan ada lima gaya kepemimpinan yaitu :

1. Kepemimpinan yang mengarahkan (direktif). Yukl (2003) menyatakan bahwa direktif leadership itu memberitahukan kepada para bawahan apa yang diharapkan dari mereka, memberi pedoman yang spesifik, meminta para bawahan untuk mengikuti peraturan-peraturan dan prosedur-prosedur, mengatur waktu dan mengkoordinaasi pekerjaan mereka.

2. Kepemimpinan yang mendukung (supportifve) Yukl (2003) mengatakan apabila tugas tersebut terlalu menekan (stresfull),membosankan atau berbahaya, maka supportif akan menyebabkan meningkatnya usaha dan kepuasaan bawahan dengan cara meningkatkan rasa percaya diri, mengurangi ketegangan dan meminimalisasi aspek-aspek yang tidak menyenangkan.

3. Kepemimpinan Partisipatif. Gaya kepemimpinan dimana mengharapkan saransaran dan ide mereka sebelum mengambil suatu keputusan. Apabila bawahan merasa mempunyai kemampuan yang baik, gaya kepemimpinan drektif akan dirasa berlebihan, bawahan akan cenderung memusuhi, sehingga gaya kepemimpinan partisipatif lebih sesuai. Kebutuhan untuk berkembang rendah dan pegawai mengerjakan tugas-tugas yang mudah, sikap yang dianggap tepat untuk pegawai yang secara ego terlihat dengan pekerjaan dan mengalami kepuasaan intrinsik dari tugas yang dikerjakan adalah sikap partisipatif dan berorientasi prestasi House dan Mitchell (1974) dalam (Yukl 2003).

4. Kepemimpinan yang berorientasi pada pencapaian (prestasi). Yukl (2003) menyatakan bahwa tingkah laku individu didorong oleh need for achievement atau kebutuhan untuk berprestasi. Kepemimpinan yang berorientasi kepada prestasi (achievement) dihipotesakan akan meningkatkan usaha dan kepuasaan 
bila pekerjaan tersebut tidak terstruktur (misalnya kompleks dan tidak diulangulang) dengan meningkatkan rasa percaya diri dan harapan akan menyelesaikan sebuah tugas dan tujuan yang menantang. Kepuasaan kerja lebih tinggi diperoleh apabila telah melaksanakan prestasi kerja yang baik.

Pegawai yang memiliki kebutuhan untuk berkembang dan mengerjakan tugastugas sulit berdasarkan pembahasan konseptual House \& Mitchell (1974) dalam Yukl (2003) sikap pemimpin yang paling tepat untuk pegawai ini adalah gaya partisipatif dan berorientasi prestasi.

5. Dalam kepemimpinan gaya pengasuh, sikap yang mungkin tepat adalah campur tangan minim dari pemimpin. Dimana pemimpin hanya memantau kinerja tetapi tidak mengawasi secara aktif. Tidak dibutuhkan banyak interaksi antara pemimpin dengan pegawai sepanjang kinerja pegawai tidak menurun. Pimpinan merasa lebih tepat untuk campur tangan dengan tugas-tugas pegawai (Yukl, 2003).

Penelitian Iowa University yang dilakukan oleh Roland Lippit, Talph K, White, dibawah bimbingan (Kurt Lewin pada tahun 1930-an dalam Luthans, 2006) menghasilkan tiga gaya kepemimpinan, yaitu :

1. Otokratis (Autocratic). Pemimpin memegang kekuasaan secara penuh, kekuasaannya bersifat sentralistik, menekankan kekuasaan jabatan, dilaksanakan dengan paksaan serta memegang system pemberian hadiah dan hukuman.

2. Bebas kendali (Laissez faire). Pemimpin memberikan kebebasan penuh kepada bawahannya untuk melakukan apa saja. Peran aktif dilakukan oleh anggota Institusi yang bebas memilih cara bekerja.

3. Demokratis (Democratic). Pemimpin yang mendelegasikan wewenang pada bawahan, mendorong partisipasi bawahan, menekankan kemampuan bawahan 
dalam menyelesaikan tugasnya, dan memperoleh penghargaan melalui kekuasaan pengaruh, bukan jabatan.

\section{Motivasi}

Motivasi berasal dari kata Latin "Movere" yang berarti dorongan atau daya penggerak. Motivasi ini hanya diberikan kepada manusia, khususnya kepada para bawahan atau pengikut. Motivasi mempersoalkan bagaimana caranya mndorong gairah kerja bawahan, agar mereka mau bekerja keras dengan mmberikan semua kemampuan dan ketrampilannya untuk mewujudkan tujuan perusahaan. Pada dasarnya perusahaan bukan saja mengharapkan karyawan yang mampu, cakap dan terampil, tetapi yang terpenting mereka mau bekerja giat dan berkeinginan untuk mencapai hasil kerja yang optimal. Kemampuan kecakapan dan ketrampilan karyawan tidak ada artinya bgi perusahaan, jika mereka tidak mau bekerja keras dengan mempergunakan kemampuan, kecakapan dan keterampilan yang dimilikinya. Motivasi penting karena dengan motivasi ini diharapkan setiap individu karyawan mau bekerja keras dan antusias untuk mencapai produktivitas kerja yang tinggi.

Pemimpin perusahaan adalah seorang yang bekerja dalam mencapai sukses dengan dan atau melalui orang lain. Atau dengan perkataan lain pemimpin perusahaan akan sukses dengan gemilang di dalam memimpin usahanya adalah:

1) Bila mampu brsama-sama dengan karyawan untuk melaksanakan berbagai aktivitas bisnisnya.

2) Bila ia mampu memanfaatkan dengan tepat guna berbagai kinerja yang dimiliki para karyawan untuk diarahkan kepada pencapaian tujuan yang telah ditetapkan terlebih dahulu. 
Untuk mencapai hal tersebut seorang pemimpin sangat berkepentingan untuk memahami karyawan yang berperilaku tertentu agar dapat mempengaruhinya untuk bekerja keras sesuai dengan yang diinginkan oleh pemimpin seniri. Kreitner dan Kinicki (2005) mengemukakan bahwa perilaku karyawan ditinjau dari kepentingan pengkajian motivasi dalam kenyataannya dapat digolongkan tiga kelompok secara garis besarnya yaitu :

1) Ada sekelompok karyawan yang bekerja keras di dalam mencapai tujuan perusahaan.

2) Ada sekelompok karyawan yang bekerja biasa-biasa saja atau belum sepenuhnya mencurahkan potensi yang dimilikinya, dan

3) Ada sekelompok karyawan yang malas atau acuh tak acuh terhadap pencapaian tujuan perusahaan.

Kegiatan pemimpin yang ada hubungannya dengan motivasi merupakan salah satu kegiatan manajemen yang mendasar yang berhubungan dengan permasalahan manusia. Karena motivasi itu pada hakekatnya akan mampu mengerahkan segala potensi karyawan kearah pencapaian tujuan.

Menurut Maslow dalam Siagian (2007) terdapat tiga implikasi dan pengertian motivasi tersebut adalah sebagai berikut :

1) Perumusan kebijaksanaan SDM tersebut di atas adalah menyangkut motivasi merupakan kebijaksanaan yang secara tidak sengaja dan terencana dirumuskan oleh pemimpin perusahaan melalui serangkaian kegiatan tertentu seperti mencari tahu tentang motif dan harapan-harapan karyawan, jadi kebijaksanaan motivasi tidak dapat dirumuskan secara spontanitas bila menginginkan hasil yang optimal terhadap dampak positif dari motivasi. 
2) Motivasi menyangkut persoalan perilaku manusia, artinya aktivitas apa yang diharapkan dari karyawan tertentu sehubungan dengan kebijaksanaan motivasi yang dirumuskan oleh pemimpin. Sehubungan dengan itu maka pemimpin perusahaan harus dapat memahami tentang berbagai kemampuan yang dimiliki oleh karyawan yang dihubungkan dengan tugas dan tanggun jawab. Keterpaduan dua hal ini akan menjadikan kebijaksanaan motivasi yang dirumuskan oleh pemimpin akan memiliki nilai guna dan tepat guna di dalam proses pembentukan perilaku karyawan.

3) Hampir dapat dipastikan bahwa motivasi senantiasa berhubungan dengan unsur manusia dalam suatu perusahaan. Manusia adalah mahkluk sangat misterius, artinya sulit untuk dipahami secara tuntas, untuk itu pimpinan di dalam merumuskan kebijaksanaan motivasi harus memadukan unsur cipta rasa dan karsa.

1) Bahwa hasil-hasil tersebut akan menjadi, pada keadaan keseimbangan, penarik efektif bagi mereka.

Lebih lanjut vroom menyatakan orang dimotivasi untuk bekerja bila mereka :

1.) Mengharapkan usaha-usaha yang ditingkatkan akan mengarah ke balas jasa tertentu, dan

2.) Menilai balas jasa sebagai hasil dan usaha-usaha mereka. Sebagai contoh : jika seseorang karyawan mengharapkan bahwa menyelesaikan pekerjaan pada waktunya akan memperoleh penghargaan, maka dia akan dimotivasi untuk memenuhi sasaran.

\section{KERANGKA PEMIKIRAN}

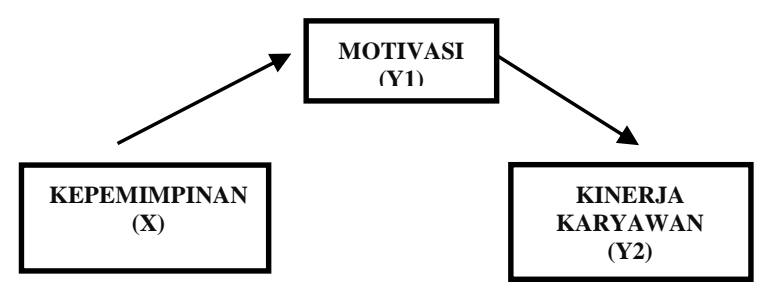


Kerangka konsep penelitian yang disusun menggambarkan pengaruh langsung variabel kepemimpinan (X1), terhadap Motivasi (Y1), kepemimpinan (X1), terhadap kinerja (Y2), dan Motivasi (Y1) terhadap kinerja (Y2). Tiap-tiap variabel memiliki indikator-indikator yang akan diukur serta digunakan untuk mendapatkan penilaian dari para responden di dalam suatu pernyataan kuesioner.

Berdasarkan kerangka konsep penelitian maka dirumuskan hipotesis penelitian sebagai berikut.

H1: Kepemimpinan berpengaruh positif dan signifikan terhadap kinerja.

H2: Kepemimpinan berpengaruh positif dan signifikan terhadap motivasi karyawan.

H3: Motivasi berpengaruh positif dan signifikan terhadap kinerja karyawan.

\section{METODE PENELITIAN}

Tahap awal yang dilakukan dalam penelitian ini adalah menentukan ukuran sampel yang akan digunakan. Penelitian ini menarik sampel dengan menggunakan metode atau teknik proportionate stratified random sampling, dimana jumlah sampel ditentukan dengan menggunakan rumus dari Sugiyono (2013) sebagai berikut

$$
s=\frac{\lambda^{2} \cdot N \cdot P \cdot Q}{d^{2}(N-1)+\lambda^{2} \cdot P \cdot Q} \ldots \ldots \ldots .1
$$

Dimana :

$\mathrm{s} \quad=$ Jumlah Sampel

$\lambda^{2}=$ Chi kuadrad yang harganya tergantung derajat kebebasan dan tingkat kesalahan.

Untuk derajat kebebasan 1 dan tingkat kesalahan 5\% harga Chi kuadrad $=3.841$. 
$\mathrm{N}=$ Jumlal Populasi

$\mathrm{P}=$ Peluang Benar $(0,5)$

$\mathrm{Q}=$ Peluang Salah $(0,5)$

$d^{2}=$ Perbedaan antara sampel yang diharapkan dengan yang terjadi. Perbedaan $5 \%$.

Berdasarkan rumus di atas dengan jumlah populasi 152 orang dan presisinya $5 \%$, maka dihitung sebagai berikut :

$$
\begin{aligned}
& \mathrm{S}=\frac{3,841 \times 152 \times 0,5 \times 0,5}{0,05^{2}(152-1)+3,841 \times 0,5 \times 0,5} \\
& \mathrm{~S}=109,107 \\
& \mathrm{~S}=\mathbf{1 1 0}
\end{aligned}
$$

Besarnya sampel adalah 110 orang karyawan.

Pengambilan sample bertingkat menggunakan rumus Riduan, (2007) sebagai berikut:

$$
\mathrm{ni}=\frac{N i}{N} x \quad n \ldots \ldots \ldots \ldots \ldots . \ldots 2
$$

Dimana : ni $=$ jumlah sampel menurut stratum

$$
\mathrm{n}=\text { jumlah sampel seluruhnya }
$$

\begin{tabular}{|c|c|c|c|c|}
\hline \multirow{2}{*}{$\begin{array}{c}\mathbf{N} \\
\mathbf{0}\end{array}$} & \multicolumn{2}{|c|}{ Nama unit kerja } & \multirow{2}{*}{$\begin{array}{c}\text { Jumlah } \\
\text { Karyaw } \\
\text { an }\end{array}$} & \multirow{2}{*}{$\underset{1}{\text { Sampe }}$} \\
\hline & Direktorat & $\begin{array}{c}\text { Bagia } \\
\mathbf{n}\end{array}$ & & \\
\hline 1. & $\begin{array}{c}\text { Sumber } \\
\text { Daya } \\
\text { Manusia }\end{array}$ & 2 & 23 & 17 \\
\hline 2. & $\begin{array}{c}\text { Humas dan } \\
\text { Protokol }\end{array}$ & 2 & 17 & 12 \\
\hline 3. & Keuangan & 2 & 27 & 20 \\
\hline 4. & $\begin{array}{l}\text { Logistik dan } \\
\text { Informasi }\end{array}$ & 3 & 65 & 47 \\
\hline 5 & $\begin{array}{c}\text { Perencanaan } \\
\text { dan }\end{array}$ & 2 & 20 & 14 \\
\hline
\end{tabular}

$\mathrm{Ni}=$ jumlah populasi menurut stratum

$\mathrm{N}=$ jumlah populasi seluruhnya

\section{Tabel 2. Komposisi Besar Sampel Berdasarkan Unit Kerja}




\begin{tabular}{|c|c|c|c|c|}
\hline & $\begin{array}{c}\text { hubungan } \\
\text { Luar Negeri. }\end{array}$ & & & \\
\hline & $\begin{array}{c}\text { Total } \\
\text { karyawan }\end{array}$ & 11 & 152 & 110 \\
\hline
\end{tabular}

Sumber: Data Diolah, 2012

Data yang akan diambil dalam penelitian ini adalah berupa data primer sedangkan metode pengumpulan data dilakukan dengan kuisioner yang diberikan kepada responden secara langsung (Sugiyono, 2013).

Instrumen penelitian ini menggunakan skala Likert 1-5. Teknik analisis yang digunakan adalah jalur path. Proses perhitungan dalam analisis ini menggunakan program komputer SPSS 13.0.

\section{HASIL PENELITIAN}

\section{Uji Validitas dan Reliabilitas}

Hasil perhitungan nilai korelasi product moment dari tiap-tiap butir pernyataan kuesioner diperoleh hasil yang besarnya di atas 0,3 . Hal ini berarti semua butir pernyataan dalam kuisioner tersebut dapat dikatakan valid. Hasil perhitungan nilai koefisien alpha dari semua variabel diperoleh nilai koefisien alpha yang besarnya di atas 0,60 . Hal ini berarti semua variabel dalam kuisioner tersebut dapat dikatakan reliabel.

\section{Analisa Deskriptif}

Pada bagian ini diuraikan penilaian atau distribusi frekuensi jawaban responden terhadap indikator-indikator pada masing-masing variabel.

Mengingat skor untuk masing-masing alternatif jawaban untuk variabel penelitian adalah minimal 1 dan maksimal 5, maka rata-rata skor pada 5 skala liker dapat diklasifikasikan sebagai berikut :

$$
1,00-1,80=\quad \text { Sangat tidak Baik }
$$




$$
\begin{aligned}
1,81-2,60= & \text { Tidak Baik } \\
2,61-3,40= & \text { Netral } \\
3,41-4,20= & \text { Baik } \\
4,21-5,00= & \text { Sangat Baik }
\end{aligned}
$$

Hasil penilaian responden adalah seperti ditunjukkan pada tabel berikut.

Tabel 3.

Penilaian Responden terhadap Variabel Kepemimpinan.

\begin{tabular}{|c|c|l|c|c|}
\hline No & Simbol & \multicolumn{1}{|c|}{$\begin{array}{c}\text { Variabel } \\
\text { Penilaian }\end{array}$} & $\begin{array}{c}\text { Hasil } \\
\text { Penilaian } \\
\text { Responden }\end{array}$ & $\begin{array}{c}\text { Kategor } \\
\text { i }\end{array}$ \\
\hline 1 & $\mathrm{X}$ & Kepemimpinan & 3.91 & Baik \\
\hline 2 & Y1 & Motivasi & 3.71 & Baik \\
\hline 3 & Y2 & $\begin{array}{l}\text { Kinerka } \\
\text { Karyawan }\end{array}$ & 3.67 & Baik \\
\hline
\end{tabular}

Sumber: Lampiran 3. Deskripsi Frekuensi

Dalam perhitungan pengolahan data, peneliti mempergunakan alat bantu yang berupa program aplikasi komputer yaitu SPSS versi 13.0.

\section{Hasil Analisi Data.}

Pada bagian ini diuraikan analisis data untuk menguji hipotesis dalam penelitian.

\section{Pengujian Hipotesis Pertama}

\begin{tabular}{|c|c|c|c|c|c|}
\hline \multirow[t]{2}{*}{ Model } & \multicolumn{2}{|c|}{$\begin{array}{c}\text { Unstandardi } \\
\text { zed } \\
\text { Coefficient } \\
\text { s }\end{array}$} & $\begin{array}{c}\text { Standardiz } \\
\text { ed } \\
\text { Coefficie } \\
\text { nts }\end{array}$ & $\mathrm{t}$ & Sig. \\
\hline & $\mathrm{B}$ & $\begin{array}{c}\text { Std. } \\
\text { Erro } \\
r\end{array}$ & Beta & & \\
\hline 1 (Constant & 1.298 & .371 & & $\begin{array}{r}3.49 \\
0\end{array}$ & $\begin{array}{r}.00 \\
0\end{array}$ \\
\hline $\begin{array}{l}\text { Kepemimp } \\
\text { inan }\end{array}$ & $\begin{array}{r}.60 \\
6\end{array}$ & .091 & .541 & $\begin{array}{r}6.68 \\
5\end{array}$ & $\begin{array}{r}.00 \\
0 \\
\end{array}$ \\
\hline
\end{tabular}

Analisis data untuk menguji hipotesis pertama menggunakan formula (1).disajikan pada Tabel 4.

Tabel 4. Hasil Regresi pada Persamaan Satu

Dependent Variabel : Motivasi 
Berdasarkan hasil analisis data pada Tabel 4.10 diperoleh bahwa kepemimpinan berpengaruh terhadap motivasi. Ini ditunjukkan oleh koefisien variabel kepemimpinan sebesar 0,606 yang signifikan dengan nilai t 6.685 pada p sebesar 0,000. Koefisien kepemimpinan yang sudah distandarisasi ditunjukkan dengan nilai beta sebesar 0,541. Hal ini berarti pengaruh langsung kepemimpinan terhadap motivasi di lingkungan Direktorat Jendral Administrasi dan Keuangan, Kementerian Estatal Timor Leste adalah 54,1\%.

\section{Pengujian Hipotesis Kedua dan Ketiga}

Analisis data untuk menguji hipotesis kedua dan ketiga menggunakan formula (2). Hasil analisis tersebut ditunjukkan pada Tabel 5.3.

Tabel 5. Hasil Regresi pada Persamaan Dua

\begin{tabular}{|c|c|c|c|c|c|c|}
\hline & Model & $\begin{array}{r}\text { Unst } \\
\text { di } \\
\text { Coef }\end{array}$ & $\begin{array}{l}\text { andar } \\
\text { zed } \\
\text { icient }\end{array}$ & $\begin{array}{c}\text { Standardi } \\
\text { zed } \\
\text { Coefficie } \\
\text { nts }\end{array}$ & $\mathrm{t}$ & Sig. \\
\hline & & & $\begin{array}{l}\text { Std. } \\
\text { Error }\end{array}$ & Beta & & \\
\hline 1 & (Constant) & $\begin{array}{r}1.03 \\
0\end{array}$ & $\begin{array}{r}.39 \\
1\end{array}$ & & $\begin{array}{r}2.63 \\
6\end{array}$ & $\begin{array}{r}.01 \\
0\end{array}$ \\
\hline & $\begin{array}{l}\text { Kepemim } \\
\text { pinan }\end{array}$ & .302 & $\begin{array}{r}.10 \\
8\end{array}$ & .264 & $\begin{array}{r}2.81 \\
2\end{array}$ & $\begin{array}{r}.00 \\
6\end{array}$ \\
\hline & Motivasi & .395 & $\begin{array}{r}.09 \\
6\end{array}$ & .387 & $\begin{array}{r}4.11 \\
4\end{array}$ & $\begin{array}{r}.00 \\
0\end{array}$ \\
\hline
\end{tabular}

Dependent variabel : Kinerja Karyawan Sumber : Data diolah, 2013

Berdasarkan hasil analisis pada Tabel 5 diperoleh bahwa kualitas kepemimpian berpengaruh terhadap kinerja karyawan. Ini ditunjukkan oleh koefisien variabel kepemimpinan sebesar 0,302 yang signifikan dengan nilai t 2,812 pada p sebesar 0,006. Koefisien kepemimpinan yang sudah distandarisasi ditunjukkan dengan nilai beta sebesar 0,264. Hal ini berarti pengaruh langsung kepemimpinan terhadap kinerja karyawan di lingkungan Direktorat Jendral Administrasi dan Keuangan, Kementerian Estatal Timor Leste adalah 26,4\%. 
Demikian pula halnya dengan motivasi berpengaruh terhadap kinerja karyawan. Ini ditunjukkan oleh koefisien variabel motivasi sebesar 0,395 yang signifikan dengan nilai t 4,114 pada $\mathrm{p}$ sebesar 0,000 . Koefisien motivasi yang sudah distandarisasi ditunjukkan dengan nilai beta sebesar 0,387. Hal ini berarti pengaruh langsung motivasi terhadap kinerja karyawan di lingkungan Direktorat Jendral Administrasi dan Keuangan, Kementerian Estatal Timor Leste adalah 38,7\%.

Selain menguji ketiga hipotesis disajikan pula jumlah variabel yang tidak diteliti dalam model penelitian (nilai error) yang ditunjukkan pada Tabel 5.4.

Tabel 6 Model Summary Persamaan Satu

\begin{tabular}{|c|c|c|c|c|}
\hline & & & & \\
$\begin{array}{c}\text { Mode } \\
1\end{array}$ & $\mathrm{R}$ & $\mathrm{R}$ & $\begin{array}{c}\text { Adjusted } \\
\text { Square }\end{array}$ & $\begin{array}{c}\text { R Square } \\
\text { Std.Error of the } \\
\text { Estimate }\end{array}$ \\
\hline 1 & $.541^{\mathrm{a}}$ & .293 & .286 & .495 \\
\hline
\end{tabular}

a. Predictors: (Constant), Kepemimpinan

b. Dependent Variable: Motivasi

Sumber : Lampiran 4, 2013

Dari hasil perhitungan berdasarkan Tabel 5.12 yang dihitung menggunakan formula (3) maka dapat dihitung nilai error yang pertama (e1) yaitu :

$$
\begin{aligned}
\mathrm{e} 1 & =\sqrt{1-\mathrm{R}^{2}} \\
& =\sqrt{1-0,293} \\
& =\sqrt{0,707} \\
& =0,841
\end{aligned}
$$

Hasil sebesar 0,841 memiliki arti bahwa jumlah varian variabel motivasi yang tidak diteliti dalam model dan berpengaruh terhadap variabel motivasi di Direktorat Jendral Administrasi dan Keuangan, Kementerian Estatal Timor Leste adalah sebesar $84,1 \%$. Nilai error yang sangat tinggi ini memberi kesimpulan bahwa tidak hanya 
kepemimpinan yang berpengaruh terhadap motivasi melainkan beberapa variabel lainnya yang berpengaruh terhadap motivasi di Direktorat Jendral Administrasi dan Keuangan, Kementerian Estatal Timor Leste. Variabel tersebut tidak diteliti dalam model penelitian ini.

Untuk menghitung nilai error pada persamaan kedua (e2) maka digunakan data yang berasal dari nilai R square pada Tabel 7. yang telah dihitung menggunakan formula (3).

Tabel 7. Model Summary Persamaan dua

\begin{tabular}{|c|c|c|c|c|}
\hline $\begin{array}{c}\text { Mod } \\
\text { el }\end{array}$ & $\mathrm{R}$ & $\begin{array}{c}\text { Squar } \\
\mathrm{e}\end{array}$ & $\begin{array}{c}\text { Adjusted } \\
\mathrm{R} \text { Square }\end{array}$ & $\begin{array}{c}\text { Std. Error of the } \\
\text { Estimate }\end{array}$ \\
\hline 1 & $\begin{array}{c}.57 \\
5^{\mathrm{a}}\end{array}$ & .330 & .318 & .494 \\
\hline
\end{tabular}

a. Predictors: (Constant), Kepemimpinan, Motivasi

b. Dependent Variable: Kinerja Karyawan

Dari hasil analisis data pada Tabel 5.13 dapat dihitung nilai pengaruh error yang kedua (e2), yaitu :

$$
\begin{aligned}
\mathrm{e} 2 & =\sqrt{1-\mathrm{R}^{2}} \\
& =\sqrt{1-0,330} \\
& =\sqrt{0,670} \\
& =0,818
\end{aligned}
$$

Hasil sebesar 0, 818 memiliki arti bahwa jumlah varian variabel kinerja karyawan yang tidak diteliti dalam model sebesar $81,8 \%$. Nilai error yang sangat tinggi ini memberi kesimpulan bahwa kinerja karyawan di Direktorat Jendral Administrasi dan Keuangan, Kementerian Estatal Timor Leste tidak hanya dipengaruhi oleh kepemimpinan dan motivasi, melainkan ada beberapa faktor lainnya 
yang mempengaruhi kinerja karyawan. Faktor-faktor tersebut tidak diteliti dalam penelitian ini.

Setelah diperoleh hasil pengujiannya maka dapat disusun hubungan antara variabel kepemimpinan, motivasi dan kinerja karyawan di lingkungan Direktorat Jendral Administrasi dan Keuangan, Kementerian Estatal Timor Leste sesuai dengan gambar 5.1.

\section{Gambar 1. Diagram Path Model Analisis}

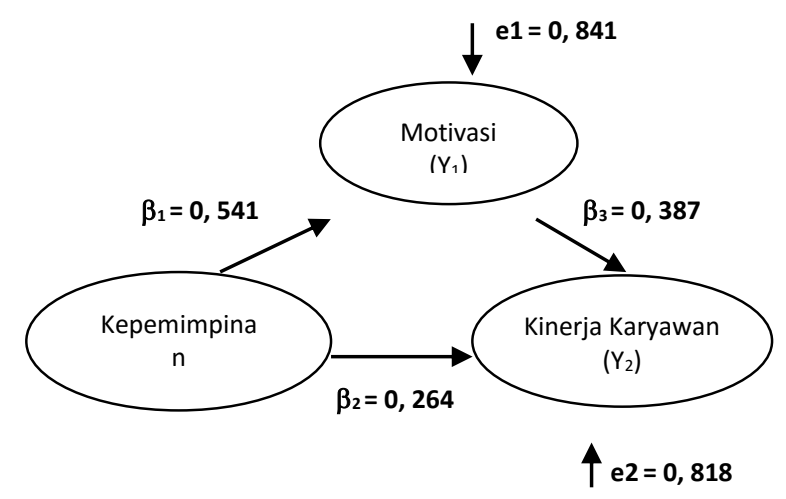

Setelah mengetahui nilai $\beta_{1}, \beta_{2}, \beta_{3}, \mathrm{e}_{1}$ dan $\mathrm{e}_{2}$, maka dapat dihitung pengaruh tak langsung dan pengaruh total dari variabel kepemimpinan pada kinerja karyawan di lingkungan Direktorat Jendral Administrasi dan Keuangan, Kementerian Estatal Timor Leste. Dari hasil perhitungan diperoleh hasil sebagai berikut :

a. Dari perhitungan tidak langsung kepemimpinan terhadap kinerja karyawan di lingkungan Direktorat Jendral Administrasi dan Keuangan, Kementerian Estatal Timor Leste dengan menggunakan formula (5) didapatkan hasil :

$$
\begin{aligned}
& =\left(\beta_{1} \times \beta_{3}\right) \\
& =(0,541 \times 0,387) \\
& =0,209
\end{aligned}
$$


Nilai sebesar 0,209 tersebut memiliki arti bahwa pengaruh tidak langsung kepemimpinan pada kinerja karyawan di Direktorat Jendral Administrasi dan Keuangan, Kementerian Estatal Timor Leste melalui motivasi adalah sebesar 0,209 atau sebesar 20,9\%.

b. Dari hasil perhitungan pengaruh total (total effect) dengan menggunakan formula (6) didapatkan hasil :

$$
\begin{aligned}
\text { Total effect } & =\beta_{2}+\left(\beta_{1} \times \beta_{3}\right) \\
& =0,264+(0,541 \times 0,387) \\
& =0,264+0,209 \\
& =0,473
\end{aligned}
$$

Hasil sebesar 0, 473 berarti bahwa besarnya pengaruh total dari kepemimpinan dan motivasi terhadap kinerja karyawan di lingkungan Direktorat Jendral Administrasi dan Keuangan, Kementerian Estatal Timor Leste adalah sebesar 47,3\%.

\section{Pemeriksaan Validitas Model}

Sesuai dengan pengujian hipotesis pada sub-sub sebelumnya maka dapat disimpulkan seluruh hipotesis (jalur) dalam penelitian adalah signifikan untuk itu tidak diperlukan adanya pemeriksaan validitas model. Dengan kata lain model yang dibangun telah mendapat dukungan secara empiris

\section{Pengujian hipotesis}

1) Hipotesa 1: menyatakan bahwa Kepemimpinan berpengaruh positif dan signifikan terhadap motivasi. Ini ditunjukkan oleh koefisien variabel kepemimpinan sebesar 0,606 yang signifikan dengan nilai t 6.685 pada p sebesar 0,000. Koefisien kepemimpinan yang sudah distandarisasi ditunjukkan dengan nilai beta sebesar 0,541 . 
2) Hipotesa 2: menyatakan bahwa Kepemimpinan berpengaruh positif dan signifikan terhadap kinerja karyawan. Ini ditunjukkan oleh koefisien variabel kepemimpinan sebesar 0,302 yang signifikan dengan nilai t 2,812 pada p sebesar 0,006. Koefisien kepemimpinan yang sudah distandarisasi ditunjukkan dengan nilai beta sebesar 0,264 .

3) Hipotesa 3: menyatakan bahwa motivasi berpengaruh positif dan signifikan terhadap kinerja karyawan. Ini ditunjukkan oleh koefisien variabel motivasi sebesar 0,395 yang signifikan dengan nilai t 4,114 pada $\mathrm{p}$ sebesar 0,000 . Koefisien motivasi yang sudah distandarisasi ditunjukkan dengan nilai beta sebesar 0,387 .

\section{PEMBAHASAN}

\section{Pengaruh Motivasi Kerja terhadap Kinerja Karyawan}

Hasil penelitian ini membuktikan bahwa motivasi kerja berpengaruh positif dan signifikan terhadap kinerja karyawan, artinya bahwa motivasi kerja memang sangat diperlukan oleh seorang karyawan untuk dapat meningkatkan kinerjanya, meskipun menurut sifatnya kinerja itu sendiri besarannya sangat relatif atau berbeda antara satu orang dengan orang lainnya. Tetapi secara keseluruhan, para responden menyatakan bahwa selama bekerja di institusi mereka menyatakan merasa puas atas motivasi kerja yang selama ini diberikan oleh pemimpin kepada para karyawan.

\section{Pengaruh Kepemimpinan terhadap Kinerja Karyawan}

Hasil penelitian ini membuktikan bahwa kepemimpinan berpengaruh positif dan signifikan terhadap kinerja karyawan, artinya kepemimpinan merupakan suatu upaya untuk memengaruhi banyak orang untuk mencapai tujuan institusi diharapkan dapat menimbulkan perubahan positif berupa kekuatan dinamis yang dapat mengkoordinasikan institusi dalam rangka mencapai tujuan jika diterapkan sesuai 
dengan koridor yang telah ditetapkan kedua belah pihak sesuai dengan jabatan yang dimiliki.

\section{Pengaruh Motivasi Kerja terhadap Kinerja Karyawan}

Hasil penelitian ini membuktikan bahwa motivasi kerja berpengaruh positif dan signifikan terhadap kinerja karyawan, artinya karyawan yang merasa puas karena telah dipenuhi kebutuhannya oleh manajemen dapat bekerja secara optimal, yaitu karyawan yang telah terpuaskan kebutuhannya merasa bahwa pemimpin telah memberikan penghargaan kepada dirinya sehingga dia merasa harus bekerja dengan profesional artinya apabila terdapat pekerjaan yang melekat pada dirinya yang sampai dengan jam kerja belum selesai tetapi dapat diselesaikan hari tersebut, karyawan tersebut bermaksud untuk menyelesaikannya karena dedikasi dan loyalitas terhadap pekerjaannya meskipun tidak diperhitungkan waktu lembur.

\section{SIMPULAN DAN SARAN}

\section{SIMPULAN}

Pada penelitian ini dapat ditarik beberapa simpulan sebagai berikut:

1) Kepemimpinan berpengaruh positif dan signifikan terhadap motivasi kerja yang ditunjukkan dengan nilai sebesar 0,006. Nilai tersebut berarti bahwa para pegawai yang bekerja di Direktorat Jendral Administrasi dan Keuangan, Kementerian Estatal Timor Leste memiliki motivasi kerja yang baik, hal tersebut berpengaruh signifikan atau memberikan pengaruh terhadap motivasi yang dirasakan oleh para pegawai tersebut.

2) Kepemimpinan berpengaruh positif dan signifikan terhadap kinerja karyawan. yang ditunjukkan dengan nilai sebesar 0,000. Nilai tersebut berarti bahwa kepemimpinan di Direktorat Jendral Administrasi dan Keuangan, Kementerian 
Estatal Timor Leste tersebut baik, hal tersebut berpengaruh signifikan atau memberikan pengaruh terhadap kinerja karyawan.

3) Motivasi kerja berpengaruh positif dan signifikan terhadap kinerja karyawan yang ditunjukkan dengan nilai 0,000. Nilai tersebut berarti bahwa pegawai yang bekerja di Direktorat Jendral Administrasi dan Keuangan, memiliki motivasi kerja yang baik, hal tersebut berpengaruh signifikan atau memberikan pengaruh terhadap peningkatan kinerja pegawai di Direktorat Jendral Administrasi dan Keuangan, Kementerian Estatal Timor Leste.

\section{SARAN}

Berdasarkan hasil penelitian, maka beberapa saran yang diberikan sebagai berikut:

1. Kelima indicator kepemimpinan yang diteliti dan berdasarkan presepsi responden menunjukkan bahwa rata-rata penilaian responden terhadap variabel kepemimpinan adalah sebesar 3,91 yang artinya baik, maka dalam hal ini hendaknya Direktorat Jenderal Administrasi dan Keuangan Kementerian Estatal selalu berupaya untuk meningkatkan kualitas kepemimpinannya sehingga dapat mempengaruhi karyawan agar giat/rajin melaksanakan tugas.

2. Kelima indicator motivasi yang diteliti dan berdasarkan presepsi responden terhadap motivasi menunjukkam bahwa rata-rata skala jawaban adalah sebesar 3.48 yang artinya baik, maka dalam hal ini hendaknya Direktorat Jenderal Administrasi dan Keuangan Kementerian Estatal selalu berupaya untuk meningkatkan motivasi kerja karyawan.

3. Direktorat Jenderal Administrasi dan Keuangan Kementerian Estatal sebaiknya mempertahankan karyawannya yang memiliki kinerja dan relasi yang luas agar ketika terjadi masalah (karyawan merasa kecewa) seorang karyawan akan 
berpikir dua kali sebelum meninggalkan Direktorat ini dan beralih pada profesi lain.

4. Lebih mengefektifkan program pemulihan (recovery program) karyawan untuk mencegah karyawan yang kinerjanya menurun dapat ditingkatkan kembali.

\section{REFERENSI}

Agustuti Handayani, 2010, Pengaruh Gaya Kepemimpinan dan Motivasi Kerja terhadap Kinerja Karyawan, Jurnal Ilmiah Administrasi Publik dan Pembangunan, Vol. 1, No 1, ISSN: 2087 - 0825.

Alimuddin, 2002, Pegaruh Gaya Kepemimpinan terhadap kinerja Pegawai Badan Pengawadan Daerah Kota Makasar, Tesis, Program Pasca Sarjana Magister Manajemen Universitas Gaja Mada (Tidak dipublikasikan).

Bass, B.M. dan Avolio, 1990, The Implications of transactional and Transformationa Team and Organization Development, . 4 , pp.23-273.

Borrill, Carol S.M.A. West and J.F. Dawson, 2005, "The relationship between Leadership and Trust Performance" Aston Business Scholl Aston University Birminghan B4 7 ET.

Didin \& Machali, 2012, Manajemen Pendidikan, Konsep dan Prinsip Pengelolaan Pendidikan, Cetakan I, AR-RUZZ MEDIA, Jogjakarta.

Dubrin Andrew J., 2005. Leadership (Terjemahan), Edisi Kedua, Prenada Media, Jakarta.

Eka Nugrah Nilova Chandrani, 2013, Pengaruh Kepemimpinan Kepala Sekolah dan Budaya Organisasi terhadap Motivasi Kerja Guru SD Negeri Kecamatan Badau, Kabupaten Belitung, Propinsi Bangka Belitung, Jurnal Evaluasi Pendidikan,Tahun 4, No. 1 (p-104-III)

Ferdinand, Augusty, 2002, Structural Equation Modeling Dalam Penelitan Manajemen. Semarans: Badan Penerbit Universitas Diponegoro.

Fillipo, Edwin B, 1994, Manajemen Personalia, Edisi Keenam, Jakarta: Penerbit Universitas Diponegoro, Semarang.

Guritno, Bambang dan Warindin, 2005, Pengaruh Persepsi Karyawan Mengenai Perilaku Kepemimpinan, Kepuasan Kerja dan Motivasi Terhadap Kinerja, JRBI, Vol. 1 No. 1, Hal. 63 - 74.

Gibson, James L.M. Ivacevivh, and Janes H. Donelly, 2006. Institusi Behavior, Structure, Processes, 5 th ed, Bossiness Publication, inc. Texas.

Hakim, Abdul, 2006, Analisa Pengaruh Motivasi, Komitmen Institusi dan Iklim Institusi Terhadap Kinerja Pegawai pada Dinas Perhubungan dan Telekomunikasi Propinsi Jawa Tengah, JRBI, Vol. 2, No. 2, Hal. 163 - 180.

Heru Purnomo \& Muhammad Cholil, 2010, Pengaruh kepemimpinan dan Motivasi terhadap berdasarkan Motivasi Kerja pada Karyawan Administrative di Universitas Sebelas Maret Surakarta, Jurnal Manajemen Sumberdaya Manusia, Vol. 4 No. 1: Pp. 27 - 35. 
Herzberg, Frederick, B. Mausner, and B, Snyderman, 1959, The Motivation New, Yurk: Wiley dalam Robbin, P, 1996, Perilaku Institusi; Konsep, Kontroversi, Aplikasi, Jakarta: Penerbit PT Prenhallindo dan dalam Dessler, Gary. 1986, Manajemen Personalia, Diterjemahkan oleh Agus Dharma, Edisi Ketiga Jakarta: Penerbit Erlangga.

Imam Fauzi, 2012, Pengaruh kepemimpinan dan Motivasi terhadap Kinerja Karyawan pada Unit SKT PT. Djarum Brak BL 53 Kudus, Jurusan Manajemen, Fakultas Ekonomi, Universitas Negeri Semarang, Indonesia, Vol. 1 No. 1; ISSN 2252-6552.

Irvan Trang, 2013,Komitmen Organisasi sebagai Mediasi pengaruh Variabel Motivasi Kerja, Gaya Kepemimpinan dan Organisasi Pelajar dengan Kinerja Karyawan pada PT. Karya Pelabuhan Indonesia IV (Persero) Canbang Blitung, Jurusan Bisnis dan Manajemen (JBM - IOSR) e - ISSM: 2778-487X. Vol 7, Issue 2. Pp $12-25$.

Kreitner, Robert, dan Kinicki, Angelo, 2005, Perilaku Institusi, Buku 1, Edisi Kelima, Jakarta: Salemba Empat.

Kreitner, Robert, and Kinicki, Angelo, 2003, Organization Behavior : Terjemahan Erly Swandy, Jakarta: Salemba Empat.

Kuncoro, Mudrajad, 2009, Metode Riset Untuk Bisnis \& Ekonomi. Jakarta Penerbit Erlangga.

Luthans, Fred, 2006, Perilaku Institusi, Edisi Sepuluh, Penerbit Andi, Yogyakarta.

Malthis, R.L dan Jackson. 2001. Manajemen Sumber Daya Manusia. Salemba Empat. Jakarta.

Mangkunegara, Anwar Prabu, 2005, Perilaku dan Budaya Institusi, Cetakan Kedua, Penerbit PT. Rafika Aditima.

Maslow, A.H., 1970, Motivation end Personality, Harper and Row. New York.

Miftah Thoha, 2012, Kepemimpinan dalam Manajemen. Edisi 1. Cetakan ke 16, Jakarta: PT. RajaGrafindo Persada.

Mulyanto, 2007, Pengaruh Kepemimpinan, Kominikasi, Kompensasi dan Motivasi terhadap Kinerka pegawai Dinas Pendapatan Daerah Kota Surakarta, Jurnal Manajemen Sumberdaya Manusia, Vol. 2 No. 1: p 27 - 35.

Nupur Chaudhary dan Bharti Sharma, 2012, Danpak Motivasi Karyawan terhadap Kinerja dalam Organisasi Swasta, International Journal of Tren Bisnis dan Teknologi - Volume 2, Issue 4, ISSN: 2249 - 0183

Rivai, Veithzal, Ahmad Fawzi Mohd. Basri 2005, Performance Appraisal, Sistem yang Tepat Menilai Kinerja Karyawan dan meningkatkan daya saing Perusahaan, Jakarta: Rajawali Perusahaan.

Rivai, Veithzal, 2004. Manajemen Sumber Daya Manusia untuk Perusahaan, PT Rajagrafindo Persada, Jakarta.

Robbinss Stephen P., 2002. Essentials of Organizational Behavior (Terjemahan), Edisi Kelima, Penerbit Erlangga, Jakarta.

Robbins, Stephen, P., 2006, Perilaku Institusi, Konsep Kontroversi Aplikasi, Jilid 1. Edisi 10, Jakarta : PT Indeks.

Robbins, Stephen, P. dan Mery Coulter, 2005, Manajemen, PT Indeks Kelompok Gramedia. Jakarta.

Ruyatnasih, H.Y., 2013, Pengaruh Gaya Kepemimpinan terhadap Kinerja Karyawan pada Bagian Operator SPBU Mitrabuana Jayalestari, Karawang, Jurnal Manajemen Vol 10, No. 3, April 2013 p 1106. 
Setiyawan, Budy dan Warindin, 2006, Pengaruuh Disiplin Kerja Karyawan dan Budaya Institusi Terhadap Kinerja di Divisi Radiologi RSUP Dokter Karyadi Semarang, JRBI, Vol. 2, No. 2, Hal. 181 - 198.

Soeprihanto, john, 2001, Penilaian Kinerja Karyawan, Yogyakarta, BPFE, Universitas Gaja Mada.

Sorvya Desianty, 2005. Peharug Gaya Kepemimpinan Terhadap Komitmen Organsasi pada PT. Pos Indonesia (PERSERO) Semarang. Jurnal Studi Manajemen \& Institusi. Vol 2. No. 1 Januari, h. 69-84.

Siagian, Sonsang P., 2007, Manajemen Sumber Daya Manusia, Cetakan ke empat, Jakarta: Bumi Aksara.

Sinambela, Lijan Polta, 2010, Reformasi Pelayanan Publik, Jakarta : Bumi Aksara.

Soegihartono, A., 2012, Pengaruh Kepemimpinan dan Kepuasan Kerja terhadap Kinerja dengan Mediasi Komitmen (di PT. Alan Kayu Sakti Semarang), Jurnal Mitra Ekonomi dan Manajemen Bisnis, Vol.3, No. 1, April 2012, 123-140 ISSN 2087-1090

Sugiyono, 2013, Metode Penelitian Kuntitatif dan Kualitatif dan $R \& D$, Cetakan ke -18 , Alfabeta, Bandung.

Suharto dan Cahyo, 2005, Pengaruh Budaya Institusi, Kepemimpinan dan Motivasi Terhadap Kinerja Sumber Daya Manusia di Sekretariat SDPRD Propinsi Jawa Tengah, JRBI, Vol. 1, No. 1, Hal. 13 - 30.

Suprayogo, Iman, 2010, Kepemimpinan; Pengembangan Institusi Team Bilding dan Perilaku Inovatif, Cetakan II, UNI-MALIKI PRES.

Surata, Sri. 2002, Dampak Motivasi Karyawan pada Hubungan antara Gaya Kepemimpinan dengan Kinerja Karyawan Perusahaan Bisnis, Jurnal Empirika, Vol. 15, No. 2, Hal. 116 - 138.

Susilo Toto Raharjo dan Durrotun Nafisah, 2006, Pengaruh Gaya Kepemimpinan terhadap Kepuasan Kerja, Komitmen Organisasi, dan Kinerja Karyawan pada Departemen Agama Kabupaten Kendal dan Departemen Agama Kabupaten Semarang, Jurnal Studi Manajemen \& Organisasi, Volume 3, Nomor 2, Juli, Tahun 2006, Halaman 77.

Sutisno, Edy. 2009, Manajemen Sumber Daya Manusia, Jakarta: Kencana.

Tampubolon, Biatna, D. 2007, Analisis Faktor Gaya Kepemimpinan dan Faktor Etos Kerja Terhadap Kinerja Pegawai Pada Institusi yang telah Menerapkan SNI 199001-2001, Jurnal Standardisasi. No. 9, Hal. 106-115.

Tika H. Moh. Pabundu, 2006. Budaya Organisasi dan Peningkatan Kinerja Perusahaan, Cetakan Pertama, PT. Bhumi Aksara, Jakarta.

Umar, Husein, 2003, Metode Riset Perilaku Institusi, Edisi Kedua, Jakarta: PT. Gramedia Pustaka Utama.

Usmara A., 2006. Motivasi Kerja, Cetakan Pertama, Puri Arsita Anam, Yogyakarta.

Veithzal Rivai, 2004, Kepemimpinan dan Perilaku Institusi, Jakarta: PT. Raja Grafindo Persada.

Vroom, H.V. \& Yago G. Arthur, 1998, The New Leadership : Managing Participation in Organization, New York, Prentice-Hall.

Wibowo, 2007, Manajemen Kinerja. Jakarta : Rajawai Pers.

Yanki Hartijasti, 2001, Hubungan antara Budaya Institusi dengan Kinerja Perusahaan, Jakarta : Salemba Empat.

Yukl, Gary, 2005, Kepemimpinan Dalam Institusi, Jakarta: PT. Indeks.

Yukl, Gary A, 2003, Managerial Leadership: A Review of Theory and Research, Journal of Management, Vol. 15, No. 2. Pp. 251-289. 
Elvino Bonaparte do Rêgo, Wayan Gede Supartha, Ni Nyoman Kerti Yasa. Pengaruh...

Yullyanti, Ellita, 2009, Analisa Ptoses Rekrutmen dan Seleksi pada Kinerja Pegawai, Journal Ilmu Administrasi dan Institusi, Vol. 16, No. 3. Pp. 131-139. 